Det saudiske regimes kamp for ny legitimitet efter det arabiske forår: En appel til ungdomsgenerationen igennem brug af retorik og symboler.

\title{
Når kongedømmet
}

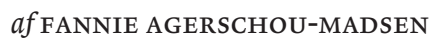

foråret 2016 tonede Saudi Arabiens Mohammed Bin Salman, ofte
refereret til som MBs, frem på den statslige nyhedsstation AlArabiya. Den daværende saudiske vicekronprins (kronprins siden 2017), forsvarsminister og formand for Rådet for Økonomi og Udvikling blev interviewet $\mathrm{i}$ anledningen af lanceringen af Vision 2030, den tiende femårsplan for udviklingen af den saudiske $\emptyset$ konomi. ${ }^{1}$ Det var og er en udviklingsplan, der repræsenterer en omfattende reformproces af både de økonomiske og sociale strukturer i det konservative Saudi Arabien. Foruden ambitioner om at diversificere olieøkonomien afslører planen også et skifte i måden regimet henvender sig til sin befolkning på. Et skifte der dækker over en rekalibrering af magtbalancen i kongedømmet og udstikker en helt ny rolle for den voksende ungdomsgeneration. Denne artikel stiller derfor spørgsmålet:

«Hvordan henvender det saudiske regime sig til sin unge befolkning i Vision 2030 og hvad afslører det om relationen mellem regimet og landets ungdomsgeneration?»

Begrebet «regime» forstås i denne kontekst som en sammenblanding af system og administration, hvor administrationen bibeholder magten igennem undertrykkelse. ${ }^{2}$ Det saudiske regime er desuden karakteriseret ved at være et autokratisk enevælde uden parlamentarisme eller demokratisk deltagelse, hvis man ser bort fra de mindre indflydelsesrige Shura-råd, der kun fungerer som et rådgivende organ. Ligeledes er den markante undertrykkelse af al politisk opposition og kritik af kongehuset definerende for det politiske landskab. En undertrykkelse der især har eskaleret siden det arabiske forår i 2011. ${ }^{3}$

Den tiende saudiske udviklingsplan Vision 2030 har siden lanceringen i 2016 fået stor opmærksomhed i internationale medier, hvor nyhedsmedier havde travlt med at lykønske Mohammed Bin 


\section{bejler til ungdommen}

Salman med det der blev fremstillet som «ambitiøse reformplaner». F.eks. beskrev journalisten Thomas Friedman i The New York Times MBS som reformator og en moderne statsmand, der ville gøre op med landets lange tradition for korruption og nepotisme ${ }^{4}$ - et interview der blev bragt oversat i Politiken.

\section{Bidrag til forskningen}

Inden for mellemøstforskningen, herunder særligt de samfundsfaglige discipliner der fokuserer på Saudi Arabien generelt, har Vision 2030 også fået stor opmærksomhed. Her har analyserne primært behandlet planens indhold som politiske intentioner og forholdt sig til reformprogrammet. Litteraturen kan for et overbliks skyld deles op i særligt tre overordnede aspekter, selvom der selvsagt er overlap. Den ene gren af litteraturen omhandler indholdet af de økonomiske reformplaner og ambitionerne med at diversificere den saudiske økonomi væk fra afhængigheden af olie og betydningen af reformerne for arbejdsmarkedet ${ }^{5}$ Den anden gren har i højere grad analyseret reformernes betydning for de sociale strukturer og på ligestillingsområdet ${ }^{6}$ og den tredje gren har omhandlet Vision 2030 implikationer for religionens rolle i landet ${ }^{7}$

Denne artikel søger at bidrage til den eksisterende litteratur ved at tilføje et andet analytisk aspekt, der går ud over det politiske indhold og fors $\emptyset$ ger at belyse retorikken og symbolerne i Vision 2030 igennem en semantisk analyse. Her vil et særligt fokus være på regimets måde at fremstille, appellere til og inddrage sin befolkningen, særligt ungdommen. Det vil blive gjort ved at sammenligne med de to tidligere udviklingsplaner.

Hvor relationen mellem regime og borger selvsagt ikke kan blive fuldt belyst igennem en analyse af politiske udviklingsplaner, vil det dog kunne afsløre dynamikker, der er relevante og oplagte at bygge videre analyser på.

Hvor Vision 2030 i størstedelen af litteraturen er blevet fortolket som regimets reaktion på nødvendigheden af at reformere og diversificere $\emptyset$ konomien og arbejdsmarkedet ved bl.a. at appellere til og tiltrække udenlandske investorer, vil denne artikel fremføre argumentet, at Vision 2030 også kan ses som et redskab for regimet til at danne en alliance med og opnå legitimitet fra den unge del af sin befolkning. Her er forståelsen af begrebet «legitimitet» vigtig. Legitimitetsbegrebet i en mellemøstforskningen er blevet behandlet af et bredt udsnit af forskere, ${ }^{8}$ men denne artikel fremhæver alligevel Mark Sedgwicks definition på legitimitet, som at «en kollektiv vurdering af udførelsen af magt, igennem politik eller handling, er valid selvom den kan være upopulær.»9

I litteraturen om rentierstater ${ }^{10}$ er legitimitet ofte kædet sammen med antagelsen om en social kontrakt, hvor borgerne ud fra en rationel materialistisk betragtning stiller sig tilfredse med velfærdsydelser og politisk stabilitet til gengæld for politisk accept ${ }^{11}$. Et eksempel på det ses $\mathrm{i}$ artiklen «Saudi Arabia plans for it's economic 
future [...]» af Moshashai et al. fra 2020, hvor Vision 2030 beskrives som et opgør med den tidligere sociale kontrakt, der ifølge forfatterne er dybt forankret i det saudiske liv og hvor netop en rationel forhandling finder sted, hvor staten $i$ $\emptyset$ konomiske kriser er nødt til at vælge mellem makroøkonomisk katastrofe eller en potentiel folkelig opstand. Hvis rentier-forhandlingen bliver truet, kan staten se frem til utilfredshed hos både befolkningen og eliten (der får fordele fra staten). Det $g \varnothing r$ at regimet er udsat og sårbart i tider med en faldende oliepris ${ }^{12}$ Ved at forstå den sociale kontrakt som en rationel forhandling mellem staten og borgerne, hvor politiske rettigheder står på den ene side og $\emptyset$ konomiske goder på den anden, vil denne artikel argumentere, at man overser et vigtigt element, der også bør inddrages. Det handler om befolkningens oplevelse af agens og følelse af værdighed, der også kan skabes igennem retorik og symboler, og ikke kun igennem direkte materielle goder eller politiske rettigheder.

Den tilgang til at forstå legitimitet trækker på «verdensanskuelsesanalysen» (worldview analysis), som den blev formuleret af Mona Kanwal Sheikh (i samarbejde med Mark Juergensmeyer) i 2019 i kapitlet «The significance of worldview analysis for social sciences». Her argumenterer Sheikh, at verdensanskuelsesanalysen kan bidrage til samfundsvidenskaberne med koncepter og metoder, der udvider forståelsen af begreber som «rationalitet» og «legitimitet». ${ }^{13}$ Det centrale i den tilgang er, at kulturelle og mindre målbare faktorer som oplevelser og følelser skal inddrages stringent $i$ analyser af politiske forhold.

Dermed udfordrer denne artikel den teoretiske forståelse af «en social kontrakt» som en rationel vurdering fra begge sider $\mathrm{i}$ «kontrakten», hvor f.eks. Meijer i 2014 beskrev, at $\mathrm{i}$ «bytte for manglen på politiske- og civile rettigheder [...] modtager brede dele af befolkningen sociale rettigheder». ${ }^{14}$
Ved at fokusere på at regimets retorik og fremstilling af symboler er vigtige for den saudiske befolknings, og særligt ungdommens, konkrete oplevelse (som er det centrale i verdensanskuelsesanalysen) af repræsentation og deres vurdering af magthaverne som legitime, søger artiklen at vise, at der ikke kun er rationelle og materialistiske elementer i spil i en social kontrakt eller spørgsmålet om legitimtiet.

For at kunne belyse spørgsmålet om, hvordan Vision 2030 bliver brugt til at danne en alliance med ungdommen og give dem en særlig oplevelse af værdighed og betydning, vil denne artikel have fokus på retorikken i Vision 2030 og symbolernes betydning i formuleringen af en ny national identitet, og hvordan den retorik appellerer til ungdomsgenerationen. Således vil artiklen ikke fokusere på det politiske indhold, altså de konkrete reformplaner, og implementeringen af den politiske plan, men på måden indholdet formidles. Igennem en analyse af måden regimet kommunikerer til sin befolkning på og omtaler sin ungdomsgeneration, vil relationen mellem regimet og den saudiske befolkning blive tydeliggjort.

Når Vision 2030 er så vigtig at analysere, og ikke blot anses som en politisk plan blandt mange andre, er det med en antagelse om, at Vision 2030 symboliserer en ny måde, regimet henvender sig til sin ungdomsgeneration og fors $ø$ ger at tegne et billede af fremtidens Saudi Arabien, som netop vil appellere til den generation, der var aktive i regionen i 2011 og som regimet frygter mobiliserer sig. Som flere har vist i litteraturen, henvender Vision 2030 sig ikke kun til den saudiske befolkning, men også til omverden for både at tiltrække investorer og politiske alliancepartnere ${ }^{15}$ Dette vil dog ikke blive uddybet i denne artikel, da fokus er på relationen mellem regimet og dets egne borgere.

Saudisk ungdom på kaffebar. 


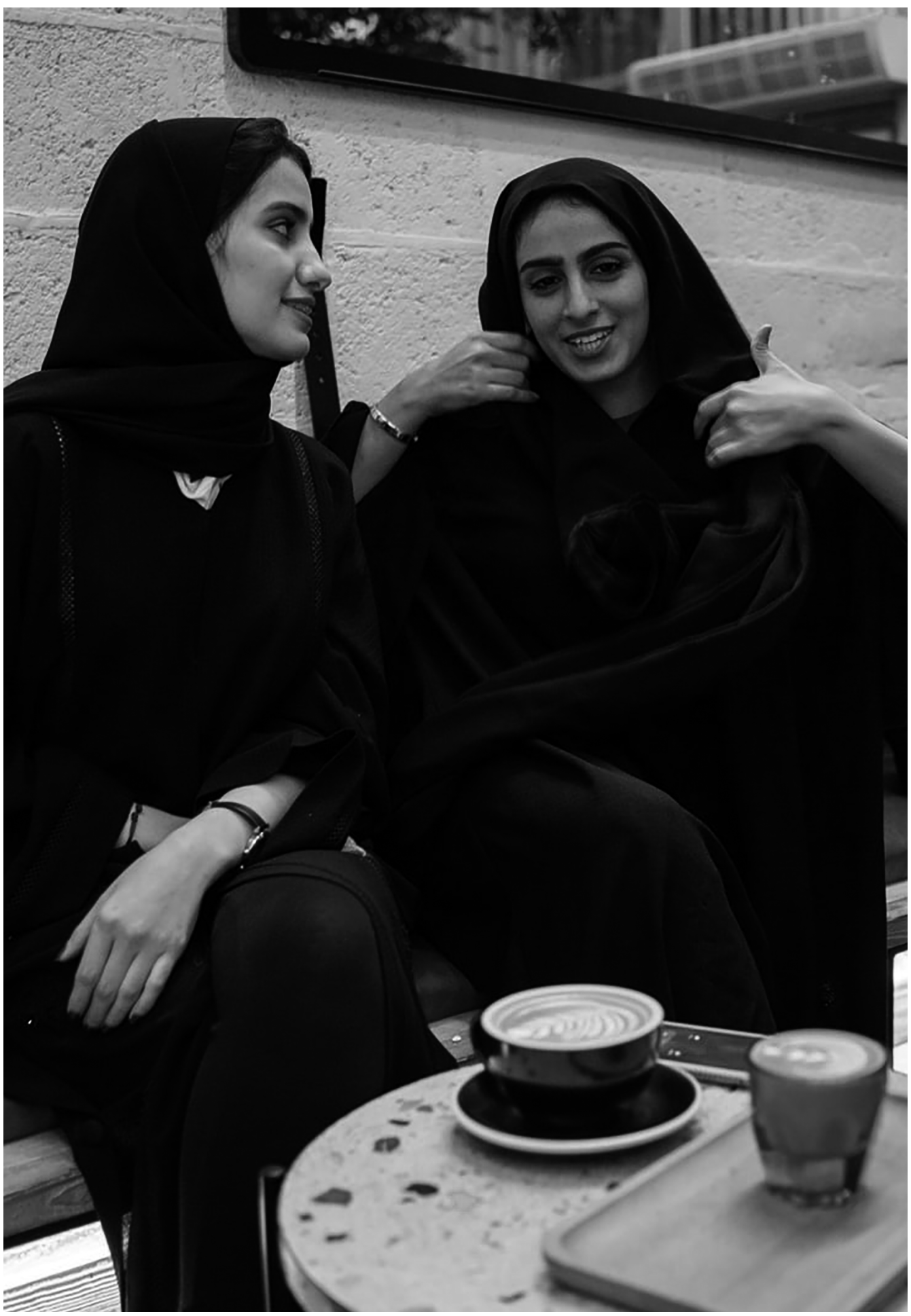


Analysens empiriske grundlag består således dels af Vision 2030, der vil blive sammenlignet med de to foregående udviklingsplaner, den ottende og niende udviklingsplan fra hhv. $2005 \mathrm{og}$ 2010, og dels af det interview MBs gav i anledningen af lanceringen af Vision 2030. En analyse af fremstillingen af ungdommen igennem alle regimets udviklingsplaner, tilbage fra 1970, har relevante og interessante aspekter, men er uden for denne artikels rækkevidde, hvor fokus primært er på Vision 2030 og den nutidige politiske situation. Ligesom denne artikel heller ikke vil beskæftige sig med spørgsmålet om, hvorfor ungdommen har spillet så lille en rolle tidligere, hvilket dog også er et interessant undersøgelsesobjekt.

\section{Retorik og symboler}

Lisa Wedeen skrev i 1999 om betydningen af retorik, symboler og metaforer i en autoritær stat i bogen Ambiguities of Domination, Politics, Rhetoric and Symbols in Contemporary Syria. Ifølge hende fører brug af succesfulde symboler og retorik til legitimitet for magthaverne og giver dem manøvrerum. En specificering af naturen af og rationalet bag symbolske fremførelser i et autoritært regime, kan hjælpe med at afklare koncepter som underkastelse, medvirken, magt og medlemskab. ${ }^{16}$ Men symbolerne produceres ikke kun af regimet. Wedeen argumenterer, at det også vil forsøge at associere sig med kulturelle symboler, der resonerer og allerede er meningsfulde blandt befolkningen. ${ }^{17}$ Selvom Wedeens bog tager udgangspunkt i Syrien under Hafez al-Assad, kan teorien belyse det saudiske regimes brug af retorik og symboler over for ungdomsgenerationen. Centralt i denne teori står begrebet legitimitet. Når Assads regime, eller i dette tilfælde det saudiske, var optaget af legitimitet, er det fordi, at selv autoritære regimer er afhængige af, at befolkningen accepterer og til en vis grad støtter op om regimet, trods deres manglende politiske rettigheder. Et regime kan ikke forlade sig på tvang som den eneste strategi til at fastholde den politiske magt, uanset graden af undertrykkelse. Alle typer af regimer er altså afhængige af legitimitet, kombineret med tvang og kooperation. ${ }^{18}$

Når det særligt er ungdommen denne artikel fokuserer på, er det fordi, at ungdommen spiller en helt central rolle i udviklingen af både de

$$
\odot \odot \odot
$$

I den første $\varnothing$ konomiske udviklingsplan fra 1970 var der en klar ambition om at skape flere job til den voksende saudiske befolkning. $\odot \odot \odot$

$\emptyset$ konomiske, politiske og sociale strukturer. Det gør de dels pga. ungdommens store demografiske andel, de udg $\varnothing \mathrm{r}$ mere end $1 / 3$ af befolkningen, og dels fordi det særligt er de unge, der presser på i landets forandringsproces og, som jeg vil vise senere i analysen, repræsenterer symbolet på fremtidens Saudi Arabien, som regimet forsøger at gøre til en central del af den nationale identitet.

Begrebet «ungdom» vil tage udgangspunkt i Asef Bayats forståelse af youthfulness og skal i denne artikel forstås som en analytisk kategori med karaktertræk, der stammer fra en særlig «ungdomshabitus», der er udgjort af deres måde at disponere, føle og være på. Ifølge Bayat er ungdommen som udgangspunkt ikke en revolutionær klasse. Men graden af transformativt potentiale $i$ ungdommen er relativ til graden af den sociale kontrol, der bliver pålagt den. ${ }^{19}$

\section{Vision 2030 og en presset saudisk økonomi}

Lanceringen af Vision 2030 i 2016 kom efter, at den saudiske $\varnothing$ konomi i en årrække havde været særligt presset. Et massivt fald i olieprisen i 2014 bet $ø$ d, at udgifterne til offentlige $l ø$ nninger og andre faste udgifter oversteg indtægterne fra olie, der er den største indtægtskilde for Saudi Arabien ${ }^{20}$ I 2015 
varslede Den Internationale Valutafond (IMF), at landet kunne risikere at gå bankerot inden for fem år, hvis olieprisen forblev lav og det ikke lykkedes at diversificere $\varnothing$ konomien væk fra afhængigheden af indtægterne fra olieeksporten. ${ }^{21}$ Men behovet for $\varnothing$ konomiske reformer var ikke et nyt fænomen i Saudi Arabien, hvor man løbende i udviklingsplanerne kan aflæse ambitioner om at reformere bl.a. arbejdsmarkedet. I den første $\varnothing$ konomiske udviklingsplan fra 1970 var der en klar ambition om at skabe flere job til den voksende saudiske befolkning. Det var dog først i den tredje udviklingsplan fra 1980, at regeringen for alvor viste bekymring over det voksende antal migrantarbejdere og den stigende arbejdsløshed blandt saudiere. ${ }^{22}$

\section{Historiske perspektiver på arbejdsmarkedet}

Arbejdsmarkedsstrukturerne i landet stammer tilbage fra den tidlige olieindustri, hvor saudiske arbejdere i stigende grad blev ansat i den offentlige sektor og udenlandske migrantarbejdere blev importeret for at undgå etableringen af en saudisk arbejderklasse og dermed en potentiel politisk trussel. Det har haft som konsekvens, at den saudiske arbejdsstyrke helt frem til i dag stadig primært er ansat i den offentlige sektor og den private sektor primært henter sine ansatte ind fra udlandet i form af billig arbejdskraft. Antallet af migrantarbejdere er steget st $\varnothing$ t siden 1950'erne og udgør i dag $1 / 3$ af den 33 mio. store befolkning. 90 procent af dem er ansat i den private sektor og er en af grundene til den store ungdomsarbejdsløshed blandt saudiere. Den demografiske udvikling i landet betyder, at ca. 100.0oo unge saudiere kommer ud på arbejdsmarkedet hvert år og det lægger et enormt pres på staten for at skabe tilstrækkeligt med arbejdspladser. ${ }^{23}$ En opgave det endnu ikke er lykkes staten at overkomme og $\mathrm{i}$ 2020 var ungdomsarbejdsløsheden på knap 28 procent for de 15-24 årige ${ }^{24}$ Den store ungdomsar- bejdsløshed er dog ikke udelukkende en $\emptyset$ konomisk udfordring for Saudi Arabien, det har også store politiske konsekvenser, hvor mange unge arbejdsløse føler sig marginaliserede og frustrerede. ${ }^{25}$

\section{Ungdommen som politisk trussel}

I foråret 2011 blev store dele af Mellemøsten ramt af protester, der omfattede mange segmenter af befolkningerne, men centralt stod ungdommen, der over en bred kam var utilfreds og protesterede mod undertrykkelse, korruption og uretfærdighed. Særligt lød krav om værdighed, karama, ${ }^{26}$ fra mange af regionens 200 mio. unge mellem 15 og 24 år. Den store ungdomsgeneration præger de sociale, $\varnothing$ konomiske og politiske strukturer i regionen. Korruptionen og ungdomsarbejdsløsheden i Mellemøsten, der er på sit højeste niveau i 25 år, udgør nogle af de unges største bekymringer. $^{27}$

I Saudi Arabien er ungdomsgenerationen den største demografiske gruppe i landet, hvor de 1534 årige udgør 36,7 procent af befolkningen. ${ }^{28}$

Der er forholdene for de unge særligt sat på spidsen. På den ene side mangler de job, har begrænsede sociale rettigheder og føler sig marginaliserede. $^{29}$

På den anden side er det samtidig en generation af unge, der er $\emptyset$ konomisk velstillede, berejste, storforbrugere af sociale medier og forbundet med verden omkring dem via deres smartphones. ${ }^{30} \mathrm{De}$ bor primært i byerne, er veluddannede og som illustration var der alene i USA 60.00o saudiske studerende i 2019. ${ }^{31}$ På trods af, at Saudi Arabien på mange punkter adskiller sig fra mange af de andre lande i regionen, bl.a. pga. den store indtægt fra olieeksport, er der også lighedspunkter i forhold til en stor ungdomsarbejdsløshed og kritik af korruption og mangel på politisk pluralisme.

Den 11. marts 2011 indkaldte saudiske aktivister til demonstration og døbte dagen «Vredens 
dag». Nye grupper - Den Nationale Ungdomsbevægelse og Den Frie Ungdomsbevægelse krævede et opg $ø$ r med korruption, undertrykkelse og uretfærdighed. Protesterne indeholdt også et krav om frigivelse af politiske fanger og et fokus på den stigende ungdomsarbejdsløshed. I 2011 lykkedes det regimet i Saudi Arabien at afværge politiske omvæltninger, som vi så andre steder i regionen. Det skete dels med fængsling af alle der opfordrede til protester og folk der havde tilkendegivet, at de ville deltage i protesterne, og dels med rundhåndede velfærdsydelser og lønstigninger til en værdi af 130 mia. dollar. Det underst $\varnothing t t e d e$ en politisk strategi, hvor styret fremstillede demonstranterne som agenter for Iran og styrkede retorikken omkring sekterisk konflikt. ${ }^{32}$ Særligt siden 2011 har vi altså set stigende en politisk bevidsthed blandt ungdommen, som også regimet er bevidst om. ${ }^{33}$ Oprørene i regionen i 2011 blotlagde, hvordan en mobiliseret ungdom kan udgøre en politisk trussel for regimet. ${ }^{34}$

\section{Vision 2030 og reformprocessen}

I 2016 præsenterede Mohammed Bin Salman den store reformplan Vision 2030, der endelig skulle reformere det saudiske samfund og økonomien. Den blev udviklet med støtte fra Verdenshandelsorganisation (WTO) og IMF og frembragt af internationale konsulentbureauer som McKinsey og Boston Consulting Group. Planen er siden blevet fremstillet som et paradigmeskift af både forskere, og internationale og saudiske medier med hvad der blev fremhævet som ambitiøse visioner om investeringer i grøn energi, kunstig intelligens, digitalt entreprenørskab, turisme og etableringen af en underholdningsindustri med store investeringer $i$ «ungdomskonsumerismen». 35

Sammenlignes formen på Vision 2030 med de tidligere udviklingsplaner ses den første store forskel. Hvor de tidligere udviklingsplaner er mere end 700 sider lange og teknisk komplicerede med mange henvisninger til tabeller og statistik, er Vision 2030 langt mere appellerende og tilgængelig for den bredere del af befolkningen. Vision 2030 er «kun» 86 sider lang og størstedelen er udgjort af billeder og illustrationer af målsætningerne med reformplanerne. ${ }^{36}$ Her er det tydeligt, at Vision 2030 har et større fokus på formidling end de tidligere udviklingsplaner. Det indikerer, at målgruppen i højere grad er den almindelige saudiske befolkning.

\section{De tidligere udviklingsplaner}

Kigger man på retorikken i Vision 2030 og formidlingen af indholdet ud fra Wedeens argument om, at måden, hvorpå regimet formidler, er vigtig, er der særligt nogle forskelle imellem den ottende og niende udviklingsplan, og Vision 2030, der må fremhæves.

Meget lig de tidligere udviklingsplaner, er den ottende udviklingsplan opdelt i 34 kapitler, der gør status på udfordringerne i forskellige resortområder, f.eks. «den private sektor», «arbejdsmarkedet» og «ungdommen og udvikling» og fremfører en plan for udviklingen af området. ${ }^{37}$ Ser man på området, der specifikt omhandler ungdommen, er der i den ottende plan fra 2005 en meget snæver forståelse af ungdommen som udelukkende en aldersgruppe med en stor arbejdsløshed ${ }^{38}$ Her bliver særligt de unges manglende arbejdsmoral og kvalifikationer på arbejdsmarkedet fremhævet, ${ }^{39}$ hvor de bliver fremstillet med for høje forventninger til forholdene på arbejdsmarkedet. ${ }^{40}$ Deres lave arbejdsmoral vil man imødekomme med særlige medieinitiativer. ${ }^{41}$ Den måde regimet fremstiller den unge generation på, indikerer, at de bliver anset som en udfordring snarere end en ressource.

Regimets forståelse af ungdommens $\emptyset$ nsker og behov er ligeledes meget snæver og fortolkes til primært at omfatte sportsaktiviteter. Under afsnittet «Kultur, information og ungdomsservices» 
opridser regimet, hvilke forskellige tiltag der er blevet taget for at imødekomme ungdomsgenerationen. Med undtagelse af oprettelsen af en læseklub, handler det om opførelsen af en række sportsfaciliteter, stadions og et hospital til at behandle sportsskader. ${ }^{42}$ Her stiller regimet sig uforstående over for, hvorfor ungdommen ikke i højere grad gør brug af de kulturelle tilbud, som f.eks. biblioteker, museer og læseklubber. Samtidig bliver ungdomsgenerationen beskrevet som en sårbar, udsat og ustabil befolkningsgruppe, hvor det er vigtigt at «beskytte dem imod negative påvirkninger».43

Det signalerer, at særligt den befolkningsgruppe bliver anset som passive og som nogle staten skal tage sig af og forme. Det er altså overordnet igennem ungdommens relation til arbejdsmarkedet, de bliver adresseret og ungdomskultur bliver forstået som primært værende sportskultur i den ottende udviklingsplan, og det signalerer en distance imellem regimet og dets ungdomsgeneration. Ungdommen symboliserer $\mathrm{i}$ denne plan en udfordring for regimet, forbundet med usikkerhed og udsathed.

I den niende udviklingsplan fra 2010 er der et markant skift i både indhold og måde regimet formidler på. Niende udviklingsplan er opbygget på samme måde som den ottende udviklingsplan, men alligevel ser man en forandring i den måde, regimet adresserer ungdomsgenerationen. Unges arbejdsløshed er stadig et vigtigt aspekt i den måde ungdomsgenerationen bliver omtalt på, men den bliver samtidig fremstillet mere nuanceret end i den forrige plan, hvor tiltag til at tilfredsstille ungdomsgenerationen stort set kun indbefattede sportsaktiviteter.

I den niende udviklingsplan har ungdommen sit eget afsnit, der hedder «Ungdommen og udvikling».44 Allerede dér bliver ungdommen forbundet med fremskridt på en måde, man ikke så i den ottende plan. I det indledende afsnit bliver ungdommen beskrevet som den befolkningsgruppe, der har den største påvirkning på udviklingen af de «sociale, økonomiske og kulturelle aspekter af livet» og som en generation med både et stort potentiale men også med udfordringer. Unge bliver anset som en gruppe, der skal støttes, så de kan være med til at opbygge samfundet. ${ }^{45}$

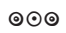

Ungdomsbegrebet udvides fra kun at indbefatte aldersgruppen 15-24 årige, til at blive defineret som en heterogen gruppe med mange forskellige behov. ๑๑

Regimet fremhæver selv, hvordan der er sket et kvalitativt skifte til den mere holistiske måde man ser ungdommen på, hvor «man medregner de mange forskellige roller unge spiller og de behov de har. ${ }^{46}$ Ligeledes udvides ungdomsbegrebet fra kun at indbefatte aldersgruppen 15-24 årige, til at blive defineret som en heterogen gruppe med mange forskellige behov og livsforhold. Alligevel finder man en underliggende kritik af den «sociale kultur, hvor ungdommen forventer, at staten finder et job til dem, uden at de selv gør en indsats».47

Hvor der ses en markant forandring i den måde regimet definerer og fremstiller ungdommen på fra den ottende til den niende, ser vi den største forandring i Vision 2030.

\section{Forsøg på alliance}

Da Vision 2030 blev præsenteret i april 2016, var det første gang en udviklingsplan blev lanceret på den måde til offentligheden. Den kun 31-årige vicekronprins Mohammed Bin Salman blev interviewet på statsligt tv, hvor han fremlagde planen som et markant skifte og som et opg ør med den saudiske afhængighed af olie. Han ønskede at Vision 2030 skulle forstås som en ambitiøs plan om at gøre Saudi Arabien til en ledende global 


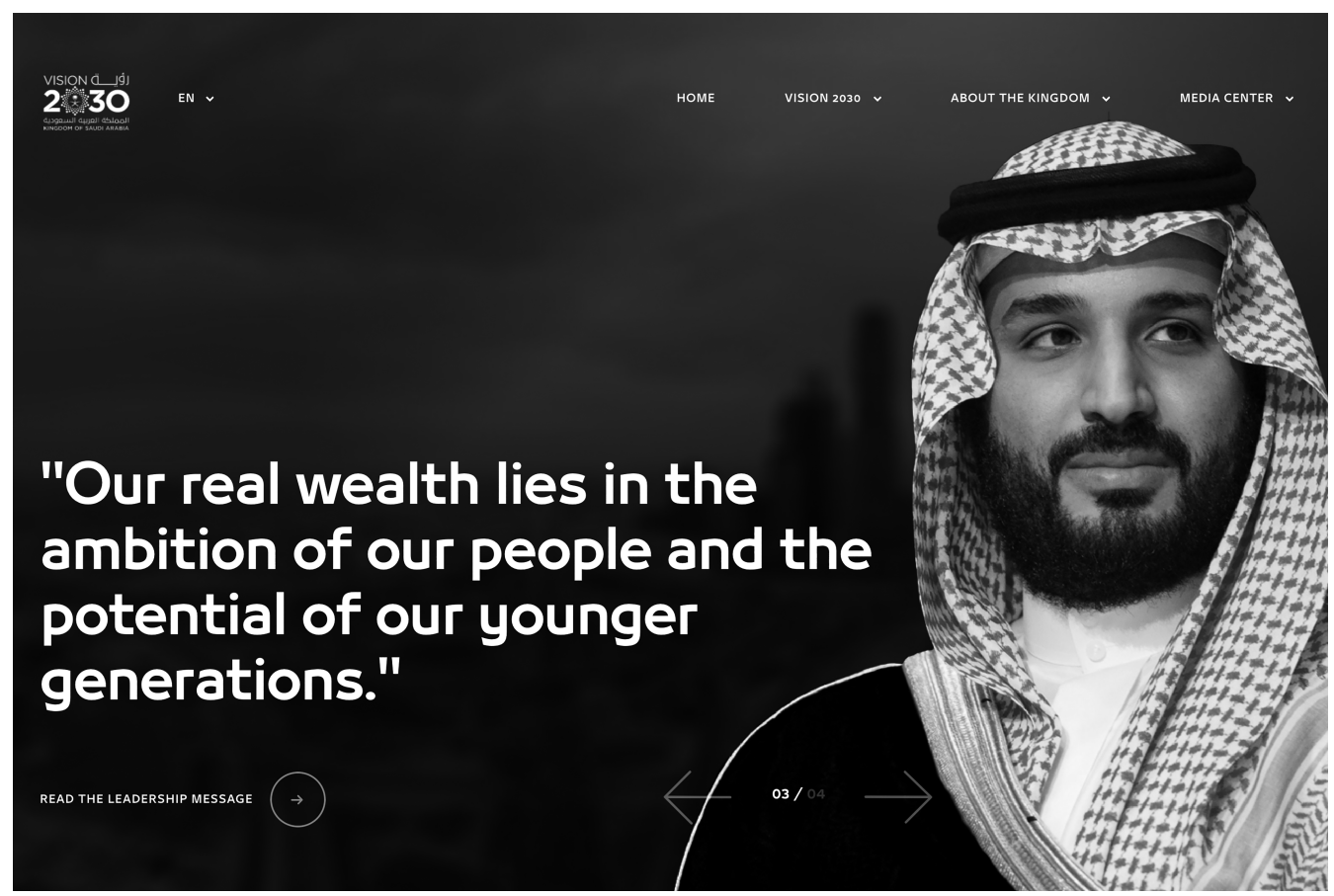

Mohammed Bin Salmans budskap på vision203o.gov.sa.

investeringsmagt. ${ }^{8}$ Parallelt med interviewet på Al-Arabiya blev Vision 2030 promoveret på diverse sociale medier, hvor også bloggere var involverede i udbredelsen af budskabet fra reformprogrammet.

Hvor de tidligere udviklingsplaner var både lange og mere tekniske med detaljerede tabeller er opbygningen i Vision 2030 erstattet af tre overordnede emner: 1) Et levende samfund, 2) En blomstrende $\varnothing$ konomi og 3) En ambitiøs nation. 49 I forordet til Vision 2030 adresserede Mohammed Bin Salman personligt den saudiske befolkning direkte og fremstillede ungdommen på en helt ny måde: «Vores største rigdom ligger i befolkningens ambitioner og vores unge generations potentiale. De er nationens stolthed og fremtidens arkitekter.» ${ }^{\circ 0}$ Pointen om den saudiske befolknings potentiale understregede han i interviewet med Al-Arabiya, hvor han beskrev «den saudiske mentalitet som en investeringsmentalitet, der vil påvirke hele verdens økonomi».

Det tegner et billede af en forandring i den måde, regimet bruger udviklingsplanen som redskab til at henvende sig til den saudiske befolkning. Ved retorisk at fremstille Saudi Arabien som et «os» skabes der et billede af et samlet hele, hvor distancen mellem regime og befolkning mindskes:

Sammen vil vi fortsatte med at bygge et bedre land, fuldende vores drom om velstand og låse op for vores unge mand og kvinders talent, potentiale og dedikation..$^{51}$

I Vision 2030 er der særlige nøgleord, der går igen igennem hele planen og som fungerer som symboler på fremtidens Saudi Arabien. Først og fremmest bliver reformprogrammet beskrevet som ambitiøst, tumuh..$^{22}$ Et nøgleord der også går igen i både mediernes dækning af Vision 2030 og 
som MBS selv bruger adskillige gange $\mathrm{i}$ interviewet med Al-Arabiya. ${ }^{53}$ Når MBs beskriver den saudiske mentalitet som en investeringsmentalitet taler han ind i et sæt værdier, der fylder enormt meget blandt unge saudiere og som også er et karaktertræk Bayat fremhæver som værende en del af en særlig ungdomshabitus.

Mark C. Thompson lavede et omfattende feltarbejde i årene efter lanceringen af Vision 2030, hvor han fandt, at mange af de unge, han talte med, mente, at Vision 2030 var vigtig, fordi planen demonstrerede ledernes $ø$ nske om at udvikle landet med input fra ungdommen. F.eks. beskrev en ung mand i et interview kort tid efter lanceringen af Vision 2030, at meningen med reformprogrammet var, at få befolkningen til at blive mere fremtidsorienteret og ambitiøs. ${ }^{54}$ MBS signalerer altså til den unge generation, at han ønsker at involvere dem og give dem en aktie i udviklingen af fremtidens Saudi Arabien. Det spiller godt ind $i$ Bayats argumenter om en særlig ungdomshabitus, som MBs her lykkes at appellere til.

Det tyder på, at der lige nu sker en redefinering af, hvad det vil sige at være borger i Saudi Arabien. Fors $\emptyset \mathrm{g}$ på at engagere ungdommen og give dem en oplevelse af at have en andel i udviklingen af landet ser vi f.eks. når unge entreprenører bliver hyldet til kæmpe messer arrangeret af MISK Foundation, der er en organisation etableret af MBs til at underst $\varnothing$ tte og investere i ungdommens uddannelse og innovation. Start-up hubs skyder frem i storbyerne Riyadh og Jeddah og ifølge initiativet «Made in Saudi», der blev lanceret i marts 2021, er der ingen grænser for, hvad unge entreprenører kan opnå i Saudi Arabien. Slogans som «Think Global - Act Saudi» signalerer retningen og den ambition der særligt er i start-up miljøer i Saudi Arabien.

\section{De allerede meningsfulde symboler}

Foruden et signal om ansvar og engagement til den unge generation, taler Vision 2030 ind $\mathrm{i}$ kerneværdier, der ifølge Thompson fylder hos de unge. «Transparens» og «troværdighed» er nøgleord, der bliver fremhævet flere gange igennem planen. Det tegner et billede af, at det er værdier regimet $\emptyset$ nsker at blive forbundet med og derigennem imødekommer regimet meget af den frustration over korruption og nepotisme, som mange unge forbinder med regimet. 55

I beskrivelsen af, hvordan regimet forstår det gode liv, går centrale nøglebegreber som «meningsfuld», haadifa, og «lykke», saeada, igen. Regimet $\emptyset$ nsker at signalere til befolkningen, at det tager ansvar for dets velvære, hvor både kunst, kultur, fritidsinteresser og underholdning skal prioriteres bl.a. igennem investeringer i underholdningsindustrien og en opblødning i de konservative sociale normer, f.eks. med en mindre streng kønssegregering. «Befolkningens glæde og tilfredsstillelse er vigtig for os. ${ }^{56}$ Det er værdier, der taler til den unge generation, der for langt de flestes vedkommende har været utilfredse med de meget konservative religiøse normer, der gjaldt $\mathrm{i}$ samfundet. ${ }^{57}$

I lyset af regimets bevidsthed om den politiske rolle en utilfreds ungdom kunne spille, som man så eksempler på i regionen i 2011, kan Vision 2030 altså også ses som en del af en større strategi om at tilfredsstille og danne en alliance med netop ungdomsgenerationen. Der er en tæt forbindelse mellem det arabiske forår i regionen i 2011 og udviklingen af Vision 2030, som vi så den lanceret blot fem år efter, at regionens autokratier blev rystet af folkelige oprør. Det er derfor ikke overraskende, at regimet har skiftet sin retorik over for befolkningen for særligt at appellere til ungdommen og signalere samhørighed. På den måde har det arabiske forår, på trods af at det ikke tilsyneladende nåede til Saudi Arabien i 2011, haft en stor påvirkning på det politiske landskab i landet alligevel. 
I MBs’ interview på Al-Arabiya i 2016 var et vigtigt budskab netop, at han mente, at ungdommen skulle hyldes. Her forklarede han, hvordan de unge var energiske, modige, havde en $h ø j$ arbejdsmoral og professionalisme, ${ }^{58}$ modsat det den niende udviklingsplan indikerede, hvor der i højere grad blev skabt en distance mellem ungdommen og regimet. På den måde talte han ind i de unges selvforståelse og skabte en samhørighed med dem. Thompson viste også i sin undersøgelse, at mange unge mænd følte sig repræsenterede af MBS og at han forstod, at man kun kunne forandre landet, hvis ungdommen blev inkluderet. De oplevede desuden, at han talte ind i deres bekym-

๑๑

Et fokus på styrets retorik og brug af symboler kan være med til at belyse og nuancere relationen mellem regimet og befolkningen. ๑๑

ringer og de udfordringer de står overfor. De oplevede, at han var troværdig og signalerede åbenhed. ${ }^{59}$ Kronprinsens kun 35 år er også en vigtig faktor $i$ regimets fremstilling af en samhørighed med ungdommen, hvor han fremstår mere opdateret og i øjenhøjde med ungdommens oplevelser og bekymringer.

På trods af, at mange af de adspurgte unge mænd var skeptiske over for realiserbarheden af Vision 2030 og de bebudede nedskæringer, lader det altså til, at det i en vis grad lykkedes MBs, og det saudiske regime, at opnå en større grad af forbindelse til den unge generation. De unges oplevelse af at føle sig repræsenterede af den daværende vicekronprins fordi «han forstår deres bekymringer», indikerer, at det ikke kun er det politiske indhold og reformerne der kan skabe legitimitet og opbakning fra befolkningen, men at det er lige så vigtigt at fokusere på den oplevelse eller følelse af at have indflydelse og medbestem- melse, befolkningen får. Da unge over hele regionen demonstrerede i 2011 og krævede vardighed, var det netop en følelse eller en oplevelse af uværdighed og ligegyldighed fra regimets side, som mange unge fremhævede. ${ }^{60}$ Ved at give ungdommen en oplevelse af værdighed og agens kan et regime finde en ny kilde til legitimitet, i hvert fald for en periode. Samtidig med at det tyder på, at det lykkedes at appellere til den unge generation og give dem en oplevelse af repræsentation og agens, stadfæstede MBs sin egen autoritet, både over for den unge befolkning, men også over for potentielle politiske udfordrere og derigennem kunne han opnå legitimitet uden at skulle give politiske rettigheder til befolkningen.

Truslen fra en potentielt politiseret ungdom, er dog ikke den eneste årsag til, at Mohammed Bin Salman ønsker at opnå legitimitet fra den unge generation. Siden han blev udråbt til kronprins $i$ 2017 har han sammen med sin far kong Salman flere gange foranlediget omstruktureringer $\mathrm{i}$ kongehuset, der har gjort op med traditionen for konsensusstyre, der ellers har præget det saudiske kongehus siden oprettelsen af den moderne stat $i$ 1932.61 Mindre end et halvt år efter han blev udråbt som kronprins gennemførte han i november 2017 det han kaldte en «omfattende antikorruptionskampagne». I en opsigtsvækkende og meget mediedækket operation blev højtstående prinser og forretningsfolk, der tidligere havde udgjort eliten i landet, fængslet på Ritz Carlton hotellet i Riyadh og fik deres finanser suspenderet. ${ }^{62}$ Den officielle forklaring var, at de hver især var under mistanke for korruption og bestikkelse, men det stod hurtigt klart, at det i langt højere grad handlede om at centralisere og cementere magten omkring kronprinsen og rydde potentielle udfordrere til tronen af vejen. Det betyder dog samtidig, at MBs blev langt mere sårbar over for kupfors $\emptyset$ g, idet der i Saudi Arabien har været tradition for et konsensusstyre, der fordelte 
magten ligeligt mellem de forskellige grene af familien. ${ }^{63}$

I den kontekst kan opbakning fra befolkningen være en vigtig strategi for kronprinsen. Det så man f.eks. i en stort opslået unders $\emptyset$ gelse fra 2018, hvor 97 procent af de adspurgte saudiere tilkendegav, at de mente, at kronprinsen var en god og stærk leder. 90 procent mente, at han førte landet i den rigtige retning og hele 92 procent mente, at Vision 2030 ville blive en succes. Mens det lader til, at der generelt er en relativt stor opbakning til den unge kronprins blandt landets unge, må man dog forholde sig skeptisk over for denne type undersøgelser, da det er svært at forestille sig, at unge saudiere vil kunne svare kritisk på den slags spørgsmål uden at frygte følgerne. Det man dog kan læse ud af unders $\emptyset$ gelsen og den tilhørende massive pressedækning i de saudiske nyhedsmedier er, at legitimitet og det at fremstå populær har stor betydning for Mohammed Bin Salman.

Hvorvidt skiftet i regimets retorik omkring ungdommen på længere sigt vil forplante sig i befolkningen og rent faktisk bidrage til en mere sikker opbakning fra den saudiske ungdom til Mohammed Bin Salman er uvist, ligesom det også er uvist, om det på sigt vil medføre en forandring $\mathrm{i}$ relationen mellem regimet og borgerne i det saudiske samfund. Men et fokus på styrets retorik og brug af symboler kan være med til at belyse og nuancere relationen mellem regimet og befolkningen.

\section{Konklusion}

Denne artikel har først fors $\emptyset \mathrm{gt}$ at vise, hvordan begrebet «legitimitet» bør udvides og også omfatte mere fleksible og svært målbare faktorer som følelser og oplevelser, som teorien om «verdensanskuelse» fremfører. Det argument er blevet udfoldet med udgangspunkt i en case, hvor det argumenteres, at udviklingsplanen Vision $2030 \mathrm{i}$ Saudi Arabien, foruden at representere en reform- proces, repræsenterer en strategi fra regimet om rent retorisk at signalere et skifte i relationen mellem regime og befolkning med et særligt fokus på ungdomsgenerationen.

Her har artiklen fors $\emptyset \mathrm{gt}$ at vise, at der er sket et markant skifte i sprogbrugen omkring de unge: Fra at omtale dem som forvænte og dovne til at forbinde dem med særlige positive symboler og nøgleord som «energiske», «professionelle» og «nationens potentiale», og at dette kan ses som et led i en strategi for at opnå legitimitet blandt den unge generation.

$$
\cdot f \cdot
$$

1 Al-Arabiya (25/4 2016) Interview med Mohammed Bin Salman. Tilgået d. 23/4 2021 på Youtube. Transkriberet på tekst: https://english.alarabiya.net/media/inside-thenewsroom/2016/04/25/Full-Transcript-of-PrinceMohammed-bin-Salman-s-Al-Arabiya-interview

2 Sedgwick, Mark. 2010. «Measuring Egyptian Regime Legitimacy», Middle East Critique, 19:3, 251-267.

3 Al-Rasheed, Madawi. 2020. The Son King. Reform and Repression in Saudi Arabia. London: Hurst Publishers.

4 Friedman, Thomas. November 23 2017. «Saudi Arabia’s Arab Spring at Last», The New York Times. Link: nytimes.com/2017/11/23/opinion/saudi-prince-mbsarab-spring.html

5 F.eks. Martin Hvidt. March 2017. «Saudi Arabia: Ambitious reform process initiated», News Analysis, Center for Mellemøststudier; Karen E Young. 2017. «Reformers are Holding Ground: Saudi Arabia's New Fiscal Policy». AGsIW series on Saudi Vision 2030. Washington D.C.: The Arab Gulf States Institute in Washington; Hilal Khashan. 2017. «Saudi Arabia’s Flawed 'Vision 2030'», Middle East Quarterly, Winter 2017; Muhammad Fauzi Abdul Rachman. 2019.' «The reality Behind the Rhetoric: An Examination of Saudi Vision 2030 Using Imminent Critique», Journal of Islamic World and Politic, Vol. 3, No. 2 (2019); Daniel Moshashai, Andrew M. Leber \& James D. Savage. 2020. «Saudi Arabia plans for its economic future: Vision 2030, the National Transformation Plan and Saudi fiscal reform», British Journal of Middle Eastern Studies, $47: 3,381-401$

6 F.eks. Martin Hvidt. April 2018. «The new role of women in the new Saudi Arabian economy», News Analysis, Center for Mellemøststudier.; Mark C. Thompson. 2018. «The Saudi 'Social Contract' Under Strain: Employment and Housing», Social Policy in the Middle East and North Africa, October 2018. POMEPS Studies 31: Middle East Political Science; Charlotte Lysa 
\& Andrew Leber. 2018. «Women's Sports Programs Are Challenging Saudi Arabia's Gender Divide», Gulf Affairs, Spring 2018. Link: oxgaps.org/files/analysis-lysa - and-leber.pdf; Ikran Eum. 2019. «'New Women for a New Saudi Arabia?' Gendered Analysis of Saudi Vision 2030 and Women's Reform Policies», Asian Women, Vol. 35, No. 3, pp. 115-133, September 2019.

7 F.eks. Eman Alhussein. (2020). «An Existential Crisis: The Diminishing Influence of Religion in the New Saudi Arabia», i Shahram Akbarzadeh (ed.), Routledge Handbook of Political Islam, ed. Shahram Akbarzadeh. Abingdon: Routledge; Stephane Lacroix. (2019). «Saudi Arabia and the Limits of Religious Reform». The Review of Faith \& International Affairs, 17(2), 97-101; Leila Makboul \& Ida Almestad (2018). «Riyadh. Arkaisk familiesete med reformambisjoner» i N. A. Butenschøn \& R. Maktabi (eds.), Brennpunkt Midtøsten. Oslo: Universitetsforlaget; Kristian Coates Ulrichsen \&Annelle Sheline (2019). «Mohammed Bin Salman and Religious Authority and Reform in Saudi Arabia». Baker Institute Report, 9.

8 F.eks. Michael C. Hudson (1977), Arab Politics, the Search for Legitimacy. UsA: Yale University Press; Oliver Sclumberger (2010) «Opening old bottles in search of new wine: on nondemocratic legitimacy in the Middle East», Middle East Critique, 19:3, pp. 233-250; Uriel Abulof (2015). «'Can’t buy me legitimacy': The elusive stability of Mideast rentier regimes», Journal of International Relations and Development, Vol. 20, No. 1,2017

9 Sedgwick 2010, 254

10 Hazem Beblawi definerede i 1987 en rentierstat som en stat, hvor skabelsen af rigdom er centreret omkring en meget lille del af samfundet. Resten af samfundet er kun involveret i distributionen og forbruget af rigdommen. Således vil der som konsekvens blive etableret en social kontrakt, hvor magthaverne tildeler befolkningen en del af rigdommen, ofte i form af velfærdsydelser, til gengæld for politiske accept.

11 Beblawi, Hazem og Giacomo Luciani (Eds.), The Rentier State (London, New York og Sydney: Croom Helm, 1987).

12 Moshashai, Daniel, Andrew M. Leber \& James D. Savage $(2020)$ «Saudi Arabia plans for its economic future: Vision 2030, the National Transformation Plan and Saudi fiscal reform», British Journal of Middle Eastern Studies, 47:3, 381-401, 383

13 Sheikh, Mona Kanwal (2019) «The significance of Worldview Analysis for Social Science», i Mona Kanwal Sheikh og Mark Juergensmeyer (eds.), Entering Religious Minds, Social Studies of Worldviews, New York: Routledge, 111

14 Meijer, Roel. 2014. «The struggle for citizenship: the key to understanding the Arab uprisings». Norge: Norwegian Peacebuilding Resource Centre, Report Feb. 2014.

15 F.eks. Moshashai et al. 2020
16 Wedeen, Lisa. 1999. Ambiguities of Domination. Politics, Rhetoric and Symbols in Contemporary Syria. Chicago og London: University of Chicago Press, 5

17 Ibid., 9

18 Sedgwick 2010, 252

19 Bayat, Asef. 2013. Life as Politics. How Ordinary People Change the Middle East (2nd ed.). Stanford University Press, kap. 5

20 Hertog, Steffen. Dec 2016. «Challenges to the Saudi distributional state in the age of austerity», Saudi Arabia: Domestic, Regional and International Challenges. Middle East Institute, National University of Singapore, 1

21 International Monetary Fund. 2015. «Regional Economic Outlook, Middle East and Central Asia, October 2015». Link: imf.org/external/pubs/ft/reo/ 2015/mcd/eng/pdf/menap1015.pdf

22 Kingdom of Saudi Arabia (KSA), Ministeriet for planlægning. 1980. Barnamij al-tanmiat al-watania: mep.gov.sa:8001/ar/development-plans

23 Agerschou-Madsen, Fannie. «Uundværlige og udskældte. Migrantarbejdernes rolle i Saudi-Arabien», Babylon, Nordisk tidsskrift for mellem øststudier, nr. 2, 2018, s. 82-93

24 Statista. 2020. «Youth unemployment rate from 1999 to 2020». Link: statista.com/statistics/812955/youthunemployment-rate-in-saudi-arabia/

25 Thompson, Mark. 2017. «Societal transformation, public opinion and Saudi youth: Views from an academic elite», Middle Eastern Studies, vol. 53, no. 5, $834-857,834$

26 Meijer 2014, 1

27 Burson Cohn \& Wolfe. 2020. «Arab Youth Survey». Link: arabyouthsurvey.com/findings.html

28 Kingdom of Saudi Arabia (KSA), General Authority for Statistics (GASTAT). 2019. Population by Age Groups and Gender: stats.gov.sa/en/43

29 Thompson 2017,834

30 Thompson, Mark. 2019. Being Young, Male and Saudi: Identity and Politics in a Globalized Kingdom. UK og New York: Cambridge University Press, 1

31 Al-Rasheed 2020, 274

32 Al-Rasheed, Madawi. 2011. «Sectarianism as CounterRevolution: Saudi Responses to the Arab Spring», Studies in Ethnicity and Nationalism, Vol. 11, No. 3 , 2011, 517

33 Thompson 2017,834 
34 Utvik, Bjørn Olav og Kjetil Selvik. 2016. Oil States in the New Middle East, Uprisings and stabilities. London og New York: Routledge, 3

35 Moshashai et al., 2020

36 Kingdom of Saudi Arabia (KSA). 2016. Vision 2030. Link: vision203o.gov.sa/

37 Kingdom of Saudi Arabia (KSA). 2005. Eight development plan. Link: mof.gov.sa/en/about/ OldStratigy/Eighth\%2oDevelopment\%2oPlan\%2o\%2oChapter\%201-8-\%D9\%85\%D8\%AF\%D9\% $85 \%$ D8\%AC.pdf

38 Ibid., 11 og 305

39 Ibid., 125

40 Ibid., 163

41 Ibid., 167

42 Ibid., 629

43 Ibid., 632

44 Kingdom of Saudi Arabia (KSA) (2010) Ninth development plan. Link: mof.gov.sa/en/about/ OldStratigy/Ninth\%2oDevelopment\%2oPlan\%20\%20Appendix-\%D9\%85\%D8\%AF\%D9\%85\%D8\%AC.pdf, 320

45 Ibid.

46 Ibid., 313

47 Ibid., 323

48 Al-Arabiya 2016

49 KSA 2016, 11

5o Ibid., 6

51 Ibid., 7

52 Ibid.

53 Al-Arabiya 2016

54 Thompson 2017,207

55 Ibid.

56 KSA 2016, 23

57 Al-Rasheed, Madawi. 2010. A History of Saudi Arabia. London: Cambridge University Press.

58 Al-Arabiya 2016

59 Thompson 2017,8

6o Meijer 2014, 1
61 Al-Rasheed 2010

62 Rahman, Kaunain. Jan. 23 2020. «An overview of orruption and anti-corruption in Saudi Arabia, Transparancy International, link: jstor.org/stable/ resrep 24897?seq=1 metadata -info-tab-contents, 9

63 Al-Rasheed 2010 